\title{
Pemberdayaan Masyarakat Dalam Rangka Pencegahan Stunting Sejak Dini di Kecamatan Pagedongan Kabupaten Banjarnegara
}

\author{
Hidayatu Munawaroh ${ }^{1}$, Moh Syakur ${ }^{2}$, Nur Fitriana ${ }^{3}$, Rifqi Muntaqo ${ }^{4}$ \\ ${ }^{134}$ Universitas Sains Al Qur'an, ${ }^{2}$ UIN Walisongo Semarang \\ 1idamunajah@gmail.com, 2moh.syakur@walisongo.ac.id,3nurdialmajid@gmail.com, \\ 3rifqimuntaqo@,unsiq.ac.id
}

\begin{abstract}
:
This study examines the problem most basic health problem for children in Indonesia today is in their growth and development, in other words, it is a problem of stunting. The government has made various efforts to prevent stunting, one of which is specifically intervening in child nutrition. In order to support government programs, we carry out a community service activity with the aim of detecting and detecting children's nutritional development. The Banjarnegara City Government has detected that 29\% of children are still affected by stunting. By involving local health workers totaling 35 cadres in these activities. In the process of implementing the activity, it is divided into 3 terms in one day, while the methods used are counseling, discussion and practice. Based on the results of the activity, the cadres experienced an increase in quality. Previously, knowledge of health cadres was only in the range of $37.14 \%$, but afterparticipating in the activity, there was a significant increase of $80 \%$. Likewise, there was an increase $(p=0.000 ;$ a $<0.05)$ since this intervention. The recommendation is that there should be activities like this on an ongoing basis and if necessary, early detection of stunting.

Penelitian ini mengkaji permasalahan kesehatan pada anak di Indonesia yang paling mendasar saat ini adalah pada pertumbuban dan perkembangannya, dengan kata lain ini adalab masalah stunting. Pemerintah telah melakukan berbagai upaya dalam menangani stunting ini, salah satunya mengintervensi gizi anak secara spesifik. Dalam rangka mendukung program pemerintah, kami melakukan suatu kegiatan pengabdian masyarakat dengan tujuan mendeteksi sekaligus mendeteksi perkembangan gizi anak. Pemerintah Kota Banjarnegara mendetelesi adanya $29 \%$ anak masib terdampak stunting. Dengan melibatkan tenaga kesehatan setempat berjumlah 35 kader dalam kegiatan tersebut. Pada proses pelaksanaan kegiatan terbagi menjadi 3 termin dalam satu hari, adapun metode yang digunakan yakni penyuluban, diskusi dan praktek. Berdasarkan hasil kegiatan, kader mengalami peningkatan kualitas. Sebelumnya pengetabuan tenaga kesehatan hanya pada kisaran 37,14\%, namun setelah mengikuti kegiatan mengalami peningkatan yang signifikan 80\%. Begitu juga, terjadi peningkatan $(p=0,000 ; a<0,05)$ semenjak adanya intervensi ini. Rekomendasinya adalah perlu adanya kegiatan seperti ini secara berkelanjutan dan bila perlu adanya pendeteksian stunting sejak dini.
\end{abstract}

Kata Kunci: Balita, Tenaga kesehatan, Stunting 


\section{Pendahuluan}

Indonesia merupakan negara berkembang yang memiliki permasalahan gizi yang buruk. Ironisnya permasalahan gizi tersebut membuat permasalahan lain yaitu stunting. Dan dstunting itu sendiri masih menjadi masalah kesehatan yang cukup serius di Indonesia dan pervelensinya tinggi. Stunting itu sendiri disebabkan karena kurangnya makanan yang bergizi bagi anak dalam bulan-bulan pertama setelah kelahiran, yang mana masa tersebut merupakan masa kritis. Gizi yang kurang atau malnutrisi ini, akhirnya mempengaruhi kondisi keseimbangan mikro dan makronutrien. Salah satu penyebabnya adalah malabsorpsi yaitu ketidakmampuan mengonsumsi nutrient. Malnutrisi dapat menyebabkan penyakit skorbut atau obesitas (UNICEF, 2012: 119-236). Pandangan badan kesehatan dunia bahwa balita memiliki kriteria tidak mencapai 2 SD maka dinyatakan pendek dan jika tidak sampai 3 SD maka dinyatakan sangat pendek (Kementererian Kesehatan RI, 2016: 2442-2763).

Data dari Kemenkes menyatakan angka kemiskinan menurun tetapi masalah stunting masih kurang baik angka perbaikannya.(Kemenkes, 2013: 2442-2766) Data menunjukan bahwa di Indonesia status gizi balita (pendek dan sangat pendek) adalah $37,2 \%$, dibandingkan dengan tahun-tahun sebelumnya dan fenomena ini tidak mengalami tren positif bagi perbaikan gizi anak. Sedangkan di Jawa Barat jumlah balita pendek sebesar 29,2\%, di Semarang 41,08\%. Organisasi kesehatan dunia memberikan kriteria batas wajar pada suatu wilayah yang terdampak stunting ini, seperti dalam suatu wilayah terdampak sedikitnya satu anak dari tiga anak balita maka ini dianggap berbahaya dan memerlukan treatmen khusus untuk menanggulanginya.

Pencegahan stunting ini penting dilakukan sejak dini, seperti ibu hamil mengkonsumsi makan yang bergizi, suplemen-suplemen yang memperkuat janin, setelah lahir diusahakan ASI ekslusif, dilanjutkan pemberian makanan-makan pendamping ASI yang berkualitas Gizi baik. Adapun faktor eksternal yang tidak kalah penting sebagai pencegahan stunting yakni pemberian pengetahuan yang cukup kepada 
tenaga medik, faktor terakhir adalah lingkungan dan Gen dari orang tua.

Ada dua ekses yang ditimbulkan dari stunting ini, jangka pendek dan jangka panjang. Dalam waktu yang singkat, jika anak kekurangan gizi akan menimbulkan masalah fisik maupun psikis dan begitu juga dalam berfikir mengalami kelambanan. Dari permasalahan diatas akan terus berdampak pada waktu yang lebih jauh, seperti anak mengalami ketinggalan belajar, tidak mampu berkompetisi dengan teman-temanya, bahkan kekebalan atau keseimbangan tubuhnya juga terus menurun.(Kemenkes, 2016: 2442-2766) Sebagai penerus bangsa seharusnya mendapatkan nutrisi yang cukup agar dapat menjadi generasi yang cerdas dan kreatif.

Kurangnya keterlibatan dan edukasi oleh petugas kesehatan dan bidan kepada masyarakat tentang makanan-makan bergizi pada masa kehamilan dan pasca melahirkan selama 2 tahun.(Arrish, dkk, 2017: 9) Berdasarkan hal tersebut diperlukan adanya upaya untuk pencegahan terjadinya stunting anak yang juga melibatkan lintas sectoral dan masyarakat dalam penyediaan pangan, air bersih dan sanitasi, penanggulangan kemiskinan, pendidikan social dan lain sebagainya (Kemenkes, 2016:2442-2766).

Data stunting di Wilayah Banjarnegara sebesar 29\%. Menurut Ketua DPC Persatuan Ahli Gizi Indonesia (Persagi) Banjarnegara Nuruddin AG, perlu adanya pembinaan dan pendampingan pada ibu hamil dengan menekankan pentingnya memakan makanan bergizi pada saat hamil, pemberian rangsangan motoric, serta bekerjasama dengan petugas Gizi yang ada di Puskemas-Puskesmas terdekat. Setelah dilakukan pemantauan, ditemukan fakta bahwa kader-tenaga kesehatan ini belum melakukan pembinaan dan pendampingan terhadap bahaya stunting kepada masyarakat, dan yang mereka lakukan pengukuran berat dan tinggi badan saja lalu mencatatnya di buku kunjungan dengan tanpa melakukan interpretasi hasil pengukuran, padahal tenaga kesehatan memiliki peran penting dalam memberikan informasi kepada ibu balita. Tenaga kesehatan juga memiliki peran kerjasama dengan petugas kesehatan dan lintas sector dalam upaya untuk meningkatkan 
kegiatan yang ada di dalam posyandu, meningkatkan kunjungan masyarakat. Sedangkan upaya yang dapat dilakukan oleh tenaga kesehatan berkaitan dengan intervensi pencegahan stunting yaitu pemantuan tumbuh kembang balita di posyandu, karena hal itu merupakan upaya strategis untuk mendeteksi sejak dini terjadinya gangguan stunting (pertumbuhan). Pencehagan sejak dini adalah salah satu cara terbaik untuk mengurangi prevalensi stunting. Prosedur yang tidak kalah penting adalah emlakukan screening rutin dan follow up tinggi badan balita yang persisten. Program posyandu pemerintah dibuat sudah sangat baik dan dapat menjadi solusi yang konkrit untuk menjangkau semua lapisan masyarakat. Semakin baik pelayanan yang dilakukan sebanding dengan peningkatan mutu kesehatan masyarakat. Proses screening rutin tinggi badan seharusnya menjadi agenda wajib dalam setiap kegiatan yang dilaksanakan di posyandu (Setyowati \& Retno, 2015: 117). Penanganan stunting itu sendiri menjadi program utama pemerintah dalam mendukung program pembangunan, oleh karena itu pencegahan stunting dan peningkatan kualitas hidup sehat masyarakat merupakan prioritas yang menggunakan dana desa. Upaya pemerintah lainnya dapat dilihat melalui media masa, komunikasi, elektronik, dam advokasi.

Keterbatasan tenaga kesehatan di Indonesia menyebabkan daya cakup pelayanan kesehatan masih belum optimal. Sehingga strategi pembangunan partisipatif adalah cara yang efektif untuk menangani masalah stunting tersebut. Partisipatif karena bukan hanya pemerintah saja yang harus sadar dan beraksi, tetapi juga masyarakat harus sadar dan mulai bergerak untuk menangani masalah stunting ini. Salah satunya adalah dengan pemberdayaan tenaga kesehatan di posyandu-posyandu yang ada di sekitar. Biasanya kasus stunting ini tidak disadari dan diketahui oleh masyarkat, sehingga perlu pemberdayaan agar mereka tahu dan mengerti tanda-tanda munculnya stunting. Apabila masyarakat mengerti dan tahu bagaimana karakteristik stunting sedini mungkin, maka segera diberikan tindakan dan penanganan yang tepat sehingga tidak menimbulkan komplikasi. 
Berdasarkan permasalahan di atas, maka kegiatan ini ditujukan pada peningkatan kemampuan sekaligus keahlian para tenaga kesehatan tentang pencegahan stunting sejak dini melalui promosi kesehatan, dan gerakan pencegahan stunting bekerja sama dengan Puskesmas setempat di Kabupaten Banjarnegara.

\section{Metode Penelitian}

Metode pelaksanaan dalam kegiatan pemberdayaan masyarakat ini yaitu cross-sectional dan keikutsertaan masyarakat. Adapun populasi penelitian ini adalah tenaga kesehatan, pemerintah desa setempat, organisasi PKK dan warga setempat. Kegiatan gerakan pencegahan stunting sejak dini dilakukan meliputi pelatihan tenaga kesehatan serta melakukan gerakan pencegahan stunting sejak dini. Pelatihan tenaga kesehatan dilakukan sebanyak 35 orang untuk mendapatkan data pengetahuan setelah dilakuakn promosi kesehatan. Data yang didapat dianalisis.

\section{Hasil dan Pembahasan}

Table 1. Distribusi frekuensi pengetahuan tenaga kesehatan mengenai pendeteksian sejak awal kemunculan stunting pada anak di Kecamatan Pagedongan Kabupaten Banjarnegara, Sebelum dan Sesudah Intervensi ( $\mathrm{N}=35)$

\begin{tabular}{lcccccc}
\hline Pengetahuan & \multicolumn{2}{c}{ Kurang } & \multicolumn{2}{c}{ Cukup } & \multicolumn{2}{c}{ Baik } \\
\cline { 2 - 7 } Kader & Frekuensi & Prosentase & Frekuensi & Prosentase & Frekuensi & Prosentase \\
& $(f)$ & $(\%)$ & $(f)$ & $(\%)$ & $(f)$ & $(\%)$ \\
Sebelum & 8 & 22,86 & 10 & 28,58 & 13 & 37,14 \\
Sesudah & 3 & 8,57 & 4 & 11,43 & 28 & 80 \\
\hline
\end{tabular}

Pada table diatas menunjukan pengetahuan tenaga kesehatan tentang stunting pada awalnya pada kisaran 37,14\%, kemudian dilakukan intervensi kadar pengetahuan tenaga kesehatan ada lonjakan yang signifikan $80 \%$. 
Tabe1 2. Pengukuran pengetahuan tenaga kesehatan memahami deteksi dini stunting

\begin{tabular}{lr}
\hline Pengetahuan Kader & \multicolumn{2}{c}{ Mean Rank } \\
\hline Sebelum & 16,3 \\
Sesudah & 8,7 \\
\hline
\end{tabular}

Hasil uji menunjukan bahwa pengetahuan yang dimiliki kader meningkat melalui kegiatan pelatihan tenaga kesehatan dalam deteksi dini stunting $(p=0,000 ; a<0,05)$.

Table 3. Distribusi Frekuensi Pengukuran Kemampuan Psikomotor Tenaga kesehatan dalam Melakukan Deteksi Dini Stunting Pada Anak

\begin{tabular}{ll}
\hline Pengetahuan Kader & Mean Rank \\
\hline Baik & 51,4 \\
Kurang Baik & 48,5 \\
\hline
\end{tabular}

Selanjutnya pada table diatas terlihat hasil pengukuran kemampuan psikomotor tenaga kesehatan dalam melakukan deteksi dini stunting pada anak. Kegiatan ini diukur dengan menggunakan lembar checklist observasi dengan pengukuran yang dilakukan satu kali setelah tenaga kesehatan mengikuti pelatihan. Berdasarkan table diatas, kemmapuan psikomotor tenaga kesehatan dalam melakukan deteksi dini stunting menunjukan sebanyak 48,5\% kade masih berada pada kategori kurang baik dalam melakukan deteksi dini stunting pada anak. Pada saat dilakukan observasi, terlihat bahwa para kade masih belum mampu melakukan dengan baik pemantuan stunting pada anak.

\section{Pembahasan}

Merujuk hasil diatas dapat dilihat bahwa terjadi perubahan pada tenaga kesehatan dalam menghadapi stunting. Sebelum dilakukan intervensi, hampir sebagian dari para tenaga kesehatan ini masih memiliki pengetahuan yang dapat dikategorikan kurang dan cukup. Namun setelah dilakukan intervensi, hanya sebagian saja yang masih dalam kategori kurang dan cukup untuk pengetahuan melakukan deteksi dini stunting. Berdasarkan hasil wawancara yang telah dilakukan, pihak puskemas mengatakan tingkat partisipasi kade kesehatan baik 
dalam mengikuti kegiatan penyuluhan yang diadakan oleh puskemas atau instansi yang lain sudah cukup baik. Hal ini memungkinkan terjadinya penyebab tidak terdapatnya kader yang memiliki pengetahuan yang kurang terkait deteksi dini stunting. Paparan informasi dari luar menjadikan para kader terpengaruh sehingga banyak informasi yang cenderung mempunyai pengetahuan yang lebih luas (Notoatmojo, 2007: 56).

Hasil uji menunjukan bahwa kegiatan pelatihan yang diberikan memberikan pengaruh yang baik terhadap peningkatan pengetahuan para kader. Metode yang diberikan pada kegiatan ini antara lain penyuluhan, diskusi, dan praktikum. Berdasarakan hasil tersebut, metode penyuluhan dirasa efektif dalam meningkatkan pengetahuan pada kader. Seperti hasil penelitian yang dilakuakn oleh Sarwani, Nurhayati, dan Supriyanti (2004 : 32), adanya perubahan pengetahuan pada tenaga kesehatan di Pekuncen dan Sumbang, baik sesudah maupun sebelum adanya pendampingan dan pembinaan terkait talasemia. Selain itu penelitain yang dilakukan oleh Fanny Adistie, dkk (2018: 180) juga mendapatkan hasil yang sama dimana metode tersebut efektif untuk meningkatkan pengetahuan.

Pada kegiatan ini metode pengajaran yag diberikan pada tenaga kesehatan tidak hanya menggunakan metode penyuluhan saja, namun juga menerapkan metode yang lain yaitu diskusi, dan praktik.penerapan metode tersebut saling menunjang tercapaianya tujuan pembelajaran yang diharapkan. Metode penyuluhan ini hampir sama dengan metode ceramah, yakni sebagai metode yang digunakan untuk penyampaian informasi secara menyeluruh dengan lisan kepada objeknya dan adanya waktu penyampaian yang terbatas oleh waktu.(Nursalam, 2008: 125) Lebih lanjut, metode ini memiliki efektifitas dalam penggunaannya. Seperti penggunanya bisa orang dewasa pada umumnya, kecukupan waktu, audiens yang berskala besar maupun kecil, dan sangat sederhana dalam media (Nursalam, 2008; Simamora, 2009; Fanny Adistie 2018: 180). Sedangkan kekurangan dari metode ini, seperti; audiens terkesan tidak aktif, terkesan doktrin, tidak adanya kritik dan saran, dan terakhir adanya perbedaan latar belakang audiens, audiens yang cenderung 
mendengar akan lebih menyukai metode ini dari pada audiens yang bertipikal visual. Selain itu juga sulit mengendalikan pemahaman peserta jika terlalu lama akan membuat jenuh (Fanny, 2018: 181).

Untuk itu dalam kegiatan ini memerlukan kombinasi dalam beberapa metode diatas. Dengan begitu diharapkan metode pendukung dapat mengatasi kelemahan dari metode tersebut. Tujuannya adalah mendorong peserta untuk dapat berfikir kritis, mengekspresikan pendapatnya secara bebas, menyumbangkan pemikirannya dalam memecahkan masalah dengan pertimbangan yang cermat. Sehingga sasaran dapat bertanaya dan mendapatkan penjelasan dari hal-hal yang masih belum dapat dipahami. Selain itu kegiatan ini juga dilaksanakan dengan menggunakan metode praktikum atau demonstrasi yaitu memperagakan benda, kejadian, aturan, dan urutan dalam melakukan kegiatan baik secara langsung maupun menggunakan media pengajaran sesuai materi yang telah diajarkan. Dengan begitu diharapkan sasaran dapat mengetahui dan memahami setiap tahapan serta cara melakukan deteksi dini stunting pada anak. Pada kegiatan ini para kader melakukan demonstrasi ulang cara mendeteksi dini stunting sesuai dengan apa yang telah diajarkan dengan bimbingan dari fasilitator, dengan tujuan retensi pengetahuan terkait hal diatas akan lebih optmal. Seperti yang diungkapkan oleh Aisyaroh, Susiloningtyas, dan Mubarok (2017: 575) yang menyebutkan bahwa tingkat pemahaman kader dari hasil prestes dan posttest meningkat setelah diberikan intervensi dengan metode demontsrasi.

Tenaga kesehatan sangat membutuhkan tambahan pengetahuan, dari pengetahuan tersebut para tenaga kesehatan merasa mampu dan percaya diri dalam melakukan tugasnya. (Notoatmodjo, 2012: 156). Pengetahuan dapat membentuk perilaku sesorang kearah yang lebih baik sesuai keilmuannya.(Effendi \&Makhfudli, 2009: 275) Berdasarkan beberpa hasil penelitian menunjukan bahwa perilaku juga didasari oleh tingkat pengetahuan yang dimiliki oleh seseorang. Penelitian yang dilakukan oleh Fatimah dan Nasution (2012: 116) misalnya mereka menyimpulkan bahwa tingkat kemampuan tenaga kesehatan melakukan pengukuran terhadap tinggi ukuran tubuh pada warga lanjut 
usia dan pembimbingan gizi berhubungan dengan peningkatan sebelum dan sesudah paltihan.

Oleh sebab itu, para kader diharaokan dapat mampu melakukan dengan baik atau meningkatkan aspek psikomotoriknya dalam melakukan deteksi dini stunting setelah diberikan wawasan serta pengetahuan melalui kegiatan pelatihan. Walaupun pada hasil observasi terkait kemampuan psikomotor masih terdapat kader yang memiliki pengetahuan dan kemampuan yang kurang sebanyak 48,5\%. Hal ini juga dapat dipengaruh oleh factor-faktor yang lain. Salah satunya dikarenakan jumlah pertemuan dan kesibukan pribadi para kader. Faktor lainnya kemungkinan terkait dengan motivasi dari kader itu sendiri. Penelitian kepada tenaga kesehatan terkait aktivitas dalam pengendalian kasus Tuberkulosis yang dilakukan oleh Wijaya, Murti, dan Suriyasa (2013: 43), menyebutkan bahwa beberapa faktor yang berhubungan dengan aktivitas tenaga kesehatan dalam pengendalian Tuberkulosis di Kabupaten Buleleng adalah pengetahuan, sikap serta motivasi dari tenaga kesehatan tersebut. Sementara kegiatan pemberdayaan tenaga kesehatan yang kami laksanakan belum menyertakan identifikasi sikap serta motivasi dari para tenaga kesehatan tersebut. Sehingga hal tersebut bisa menjadi kemungkinan masih adanya kemampuan psikomotor tenaga kesehatan yang kurang baik walaupun tingkat pengetahuannya hampir seluruhnya berada pada kategori baik.

Berdasarkan pembahasan diatas, metode yang diterapkan pada kegiatan pemberdayaan kesehatan efektif dalam meningkatkan pengetahuan tenaga kesehatan tentang deteksi dini stunting pada anak. Namun, terkait kemampuan psikomotor tenaga kesehatan dalam melakukan deteksi dini stunting anak masih perlu dilakukan upaya-upaya yang dapat mendukung peningkatan kemampuan psikomotor para kader tersebut selain dengan peningkatan pengetahuan melalui pelatihan. Upaya-upaya tersebut adalah dengan melakukan kerjasama dengan berbagai pihak terutama Puskesmas Kecamatan Jatinangor dalam hal: 
1. Edukasi berkelanjutan, misalnya setiap 6 bulan sekali untuk kader serta kegiatan penguatan peran para tenaga kesehatan secara rutin terutama terkait stunting dan tumbuh kembang anak sebagai upaya meningkatkan pengetahuan serta keterampilan tenaga kesehatan.

2. Monitoring dan evaluasi yang dilakukan secara rutin oleh pihak puskesmas terhadap para tenaga kesehatan dalam pelaksanaan penimbangan, deteksi status gizi maupun deteksi serta stimulasi tumbuh kembang anak.

3. Optimalisasi pelaporan seperti cara pencatatan yang efektif dan jelas disertai hasil interpretasi pengukuran serta kecepatan dalam penyerahan laporan hasil deteksi dini tumbuh kembang anak serta status gizi dan deteksi stunting dari para tenaga kesehatan kepada bidan desa setempat atau puskesmas.

4. Pemberian reward kepada tenaga kesehatan yang berperan aktif dalam melakukan deteksi dini stunting serta deteksi dini dan stimulasi tumbuh kembang anak sehingga dapat memotivasi tenaga kesehatan lain dalam meningkatkan performanya.

Demikian pentingnya peran tenaga kesehatan dalam meningkatkan pengetahuan dan juga kemampuan masyarakat mendeteksi stunting, sehingga berdampak baik pada perkembangan anak di usia balita. Kegiatan ini tentunya perlu dukungan dari petugas kesehatan, pemerintah desa dan kelompok masyarakat.

\section{Simpulan}

Pelaksanaan pemberdayaan tenaga kesehatan dalam deteksi dini stunting pada anak di Desa Pagedongan telah terlaksana dengan lancar dan mendapat dukungan dari Puskesmas Kecamatan Pagedongan serta perangkat Desa Pagedongan. Para tenaga kesehatan juga turut berpartisipasi dengan baik pada pelaksanaan kegiatan ini. Kegiatan yang telah dilakukan antara lain: dimulai dengan pembuatan modul mengenai deteksi dini stunting serta stimulasi tumbuh kembang, pelatihan bagi para fasilitator yang akan terlibat dalam kegiatan, lalu pelatihan kepada para tenaga kesehatan dengan menggunakan metode penyuluhan, diskusi dan tanya jawab serta demonstrasi cara melakukan 
deteksi dini stunting serta stimulasi tumbuh kembang pada anak dengan menggunakan alat peraga, kemudian para tenaga kesehatan dibagi-bagi ke dalam beberapa kelompok kecil dan didampingi oleh fasilitator untuk melakukan re-demonstrasi cara deteksi dini stunting serta stimulasi tumbuh kembang pada anak. Setelah kegiatan pelatihan, kegiatan evaluasi pelaksanaan deteksi dini stunting dilakukan saat posyandu berlangsung di RW masing-masing.

Adanya kegiatan penyuluhan ini, pengetahuan yang dimiliki tenaga kesehatan sebelumnya 37,14\% kini menjadi 80\%. Kemudian pada upaya mendeteksi stunting dan peningkatan pertumbuhan anak pada hitungan ( $\mathrm{p}=0,000 ; \alpha<0,05)$. Dengan demikian, efektifitas kegiatan ini terbukti berjalan dengan baik, dimana tenaga kesehatan terpenuhi kebutuhan informasi dan pengetahuannya tentang pendeteksian stunting dan pertumbuhan anak.[]

\section{DAFTAR PUSTAKA}

Aisyaroh, N., Susiloningtyas, I., \& Mubarok. 2017. Pengembangan Intervensi MP-ASI dengan Metode Demonstrasi pada Tenaga kesehatan Di Desa Batur Kecamatan Getasan Kabupaten Semarang. Prosiding Implementasi Penelitian Pada Pengabdian Menuju Masyarakat Mandiri Berkemajuan (pp. 573-577). Semarang: Universitas Muhammmadiyah Semarang.

Arrish, J., Yeatman, H., \& Williamson, M. 2017. Midwives' Role in Providing Nutrition Advice during Pregnancy: Meeting the Challenges? A Qualitative Study. Nursing Research and Practice, 2017(July), 1-11. https://doi. org/10.1155/2017/7698510

Effendi, F., \& Makhfudli. 2009. Keperawatan Kesehatan Komunitas: Teori dan Praktik dalam Keperawatan. Jakarta: Salemba Medika.

Kementerian Kesehatan Republik Indonesia. 2013. Riset Kesehatan Dasar 2013. Jakarta: Kementerian Kesehatan RI. 
Kementerian Kesehatan Republik Indonesia. 2016. Situasi Balita Pendek. Jakarta: Pusat Data dan Informasi Kementerian Kesehatan RI.

Fanny, dkk. 2018. Pemberdayaan Tenaga kesehatan Dalam Deteksi Dini Stunting dan Stimulasi Tumbuh Kembang pada Balita. Jurnal. Padjajaran: Universitas Padjajaran.

Notoatmodjo, S. 2007. Kesehatan Masyarakat Ilmu dan Seni. Jakarta: Karya Medika.

Notoatmodjo, S. 2012. Promosi Kesehatan dan Perilaku Kesehatan. Jakarta: Rineka Cipta.

Nursalam. 2008. Konsep dan Penerapan Metodologi Penelitian Ilmu Keperawatan, Pedoman Skripsi, Tesis dan Intrumen Penelitian Keperawatan. Jakarta: Salemba Medika.

Sarwani, D., Nurhayati, N., \& Supriyanto. 2014. Efektifitas Ceramah terhadap Pengetabuan Tenaga kesehatan tentang Penyakit Talasemia di Kecamatan Pekuncen dan Kecamatan Sumbang Kabupaten Banyumas. Kesmas, $8(1)$ 29-36. https://doi.org/http://dx.doi.org/10.12928/kesmas.v8i1.1038

Setyowati, M., \& Retno, A. 2015. Pemetaan Status Giri Balita dalam Mendukung Keberbasilan Pencapaian Millenium Development Goals (MDGs). J Kesehat Masy, 10(2), 110-21.

Simamora, H. R. 2009. Buku Ajar Pendidikan dalam Keperawatan. Jakarta: EGC.

Unicef. 2012. Ringkasan Kajian Kesehatan Ibu dan Anak. Jakarta: UNICEF Indonesia.

Wijaya, dkk. 2013. Hubungan Pengetahuan, sikap, dan motivasi Tenaga kesehatan. Buleleng: Jurnal Magister Kedokteran Keluarga.

WHO. 2013. Child Growth Indicators and Their Interpretation. http://www.who.int/\%0Anutgrowthdb/about/introduction/e n/\%0Aindex2.html. Diakses tanggal 26 Maret 2020. 